\title{
浄水污泥のリン酸除去効果の評価と 諫早湾干拓調整池適用時効果の試算
}

\author{
朝倉 宏 1）中川 啓 1）武政 剛弘 2) \\ 1) 長崎大学大学院 水産 - 環境科学総合研究科 \\ （干 852-8521 長崎県長崎市文教町 1-14） \\ 2) 株式会社地域創造長崎 \\ （ ₹ 850-0862 長崎県長崎市出島町 1-43）
}

\begin{abstract}
本研究では, 地域で活用されていない浄水污泥を有効活用して污泥の処理費を軽減させることと, 諫早湾干拓調 整池の水で環境基準值を超過している全リン濃度を低減させることの両者達成の可能性を把握するために, 浄水污 泥を用いたリン酸除去効果を評価し, 調整池に適用した際のリン酸濃度変化についてシミュレーションにより試算 することを目的とした，調整池の水をくみだし，水処理施設において浄水污泥を用いて完全混合するリン酸除去法 では，おおむね 1 年間で $1,400 \sim 2,000 \mathrm{t}$ の污泥が必要であることが分かった．調整池に浄水污泥を投入する浸漬法に よるリン酸除去法では, 1 年間で $3,000 \mathrm{t}$ の污泥が必要であることが分かった。混合法では, 巨大な吸着槽（例えば $10^{5}$ $\mathrm{m}^{3}$ のオーダー) が必要であり, 浸漬法では污泥を調整池に投入したままとなり, また調整池からリンを取り除いて いないという欠点がある. 浄水污泥はリン酸除去に利用可能であるが, 必要量や施設規模が膨大であるため, さら なる検討が必要である.
\end{abstract}

キーワード : 吸着, リン酸, 浄水污泥, 境膜物質移動容量係数

\section{I 、はじめに}

諫早湾干拓事業は, 諫早湾の湾奧を締切り, 調整 池及び調整池を水源とするかんがい用水が確保され た大規模な優良農地を造成し, 生産性の高い農業を 実現するとともに，背後の低平地において高潮，洪 水, 常時排水不良等に対する防災機能の強化を目的 としている（九州農政局, 2003）.1997年に潮受け堤 防が閉め切られ, 1999年に堤防が完成した。図ー1 に, 諫早湾干拓地と調整池の概要を示す。干拓事業 が原因の一つであると考えられている環境の変化及 び悪化がいくつかあるが, 潮受け堤防内部の調整池 の水質について, 全リン濃度をはじめ, 化学的酸素 要求量と全窒素濃度が環境基準值（ただし調整池は, いまだ環境基準の類型指定を行っていないが，長崎 県が環境基本法に基づく湖沼の環境基準を当てはめ たもの. 基準值はそれぞれ, $0.1 \mathrm{mg}-\mathrm{P} / \mathrm{L}, 5 \mathrm{mg}-\mathrm{O}_{2} / \mathrm{L}, 1$ mg-N/Lである.）を超過している（長崎県, 2008）. この原因として, 長崎県は, 流域, 新干拓地・自然 干拓地からの污染物質の負荷量が大きいことをあげ
ている（長崎県, 2008）。このような水域における水 質悪化の防止と改善は, 水資源の保全の観点から重 要な課題である（国土交通省, 2007).

一方, 浄水場から発生する浄水污泥には, リン酸 の吸着能があることが知られている（海野ら， 2003）。また, 浄水污泥は再利用率が $63 \%$ （2010年, 厚生労働省, 2010）であり, 国内の 10 万 $\mathrm{t}$ (乾燥重量) が有効利用されていない（厚生労働省, 2010）ため, 吸着剤として利用しうる。

海野ら（2003）は, 浄水污泥が持つリン酸の吸着 機構として, 浄水場の凝集剤に由来する酸化アルミ ニウムがリン酸と結合する現象をあげている。また, 土粒子（浦野, 1988）と活性炭（Boki and Tanaka, 1987）もリン酸吸着能を有する. 浄水污泥中の土粒 子は河川水等の水中に含まれていたものであるが, 諫早湾にも河川が流れ込んでいることから, 諫早湾 には十分な土粒子が供給されていると考えられる。 したがって，浄水污泥をさらに諫早湾に投入したと きの土粒子によるリン酸の吸着効果は無視しうる. 


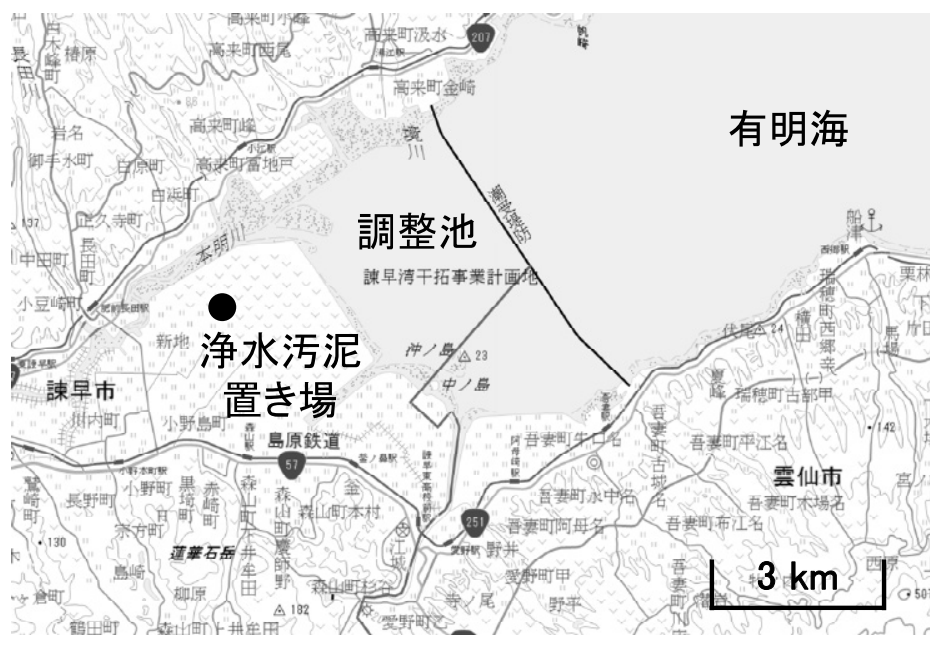

図 - 1 諫早湾干拓地と調整池（国土地理院）

Fig. 1 Isahaya reclaimed land and its adjustment reservoir (Geospatial Information Authority of Japan).

さらに, 浄水工程では臭気除去のために活性炭を添 加することがあり，この活性炭の残存能力によって リン酸が吸着される経路もありうる。ただし, 本研 究では吸着能が発揮される要因については扱わない.

浄水污泥中の酸化アルミニウムと活性炭に期待し てリン酸を吸着除去する方法を考えるならば, 単純 に酸化アルミニウム薬剤と活性炭を調整池に投入す ればよいことになる。しかし, 浄水污泥を吸着剤と して用いることの利点は, 浄水污泥が不用物である こと, 調査地とした諫早湾では干拓地に浄水污泥が 仮置きされていること, 吸着剤として用いる際には 污泥を脱水する必要なくスラリーのまま適用できる （浄水場の污泥脱水工程が省略できる）こと, 凝集 沈殿した粒子であるから, リン酸を吸着した後に再 び沈殿しやすいと考えられること，である。

諫早湾干拓調整池のリンの挙動に関する研究は, 水質変化を説明するためのモデル構築（仁木ら, 1999 ; 佐々木ら, 2003 ; 李ら, 2011) 等が見られるが, リンの低減のための対策に関する研究は無い.また, 浄水污泥によるリンの吸着に関する研究 (Kim et al., 2003 ; 海野ら, 2003 ; Yang et al., 2006）があるが, 速度論的な解析が無いために, 調整池等の実環境に 適用したときのリン濃度の低減にかかる時間と污泥 の必要量との関係が考察できない。また, 調整池が 広大であることから, 浄水污泥を調整池に適用した ときのリン濃度低減の効果はシミュレーションに よって評価する必要がある。

そこで本研究では, 地域で活用されていない浄水
污泥を有効活用して污泥の処理費を軽減させること と, 諫早湾干拓調整池の水で環境基準値を超過して いる全リン濃度を低減させることの両者達成の可能 性を把握するために, 浄水污泥を用いたリン酸除去 効果を実験的に評価し, 調整池に適用した際のリン 酸濃度変化についてシミュレーションにより試算す ることを目的とした。

なお，環境基準の対象は全リンである。実際の全 リンの削減方策のためには一部しか現象を説明でき なくなるものの, 実験の簡便さを考えてリン酸のみ を対象とした。なお，調整池表層中の全リンおよび リン酸の濃度は, それぞれ 0.228 および $0.112 \mathrm{mg}-\mathrm{P} / \mathrm{L}$ （2006～2008年の平均, 九州農政局, 2013）であり, リン酸の挙動だけに着目すると, 全リンの半分程度 を説明することになる。

\section{II. 試料と実験方法}

本研究では, 浄水場から発生する浄水污泥を吸着 剂として使用した。浄水污泥は, 諫早市平山浄水場 から発生したものである。

\section{1. 平山浄水場}

平山浄水場は, 小ヶ倉ダム水, 土師野尾ダムから 放流された東大川の水㧍よび地下水を取水してい る. 処理フローは, 沈砂池, 粉末活性炭接触槽, 着 水井, 擋拌池 (ポリ塩化アルミニウム)・フロック 形成池, 沈殿池, 万過池 (砂), 塩素滅菌浄水池 (次 
亜塩素酸ナトリウム）である。浄水污泥は, 沈殿池 で発生する，臭気除去のために粉末活性炭を添加し ており，これを含むために浄水污泥は黒色となる。 2011 年度の浄水污泥発生量は, $2,039 \mathrm{t}$ である（長崎 県, 2013).

\section{2. 吸着剤}

浄水污泥は, 中央干拓地内の浄水污泥置き場に一 時的に堆積している。この堆積物をスコップですく い取り，密閉バケツに入れて持ち帰った。

この堆積物は微細な懸濁物（粒子）を凝集・脱水 させたものである。採取時の堆積物は粘土状である が, 水中では速やかに微細な懸濁物に戻る。吸着実 験時における規定重量の測り取り，速やかな水溶液 中への分散を容易にするために, 堆積物を乾燥させ, 粉体とした。具体的には, $100 \pm 5{ }^{\circ} \mathrm{C}$ で 3 日以上乾燥 させ, ハンマーで砕き,さらに小型ミルで粉砕した。 繰り返すが, 堆積物は元が微細な粒子であるため, 小型ミルによる粉砕は, 構成粒子を粉砕することを 目的として扔らず，団粒を崩して粒子を分離するこ とを目的としている.

この乾燥粉砕物は, 黒色の粉体である. 浄水污泥 の構成母材である砂と思われる $1 \mathrm{~mm}$ 以上の粒子が 目視で確認された。吸着実験で用いる吸着剂量は最 少 $10 \mathrm{mg}$ であるため, 砂の存在は吸着能力評価時の 誤差要因として大きいと考えられる。この粒子には リン酸の吸着能力が無いと考えられるので, 目開き $0.5 \mathrm{~mm}$ のステンレスふるいで分級し, 通過分を吸着 剂とした。 なお，ふるい残留分は，乾燥粉砕物の $1 \%$ 未満である.

またリン酸溶液は, リン酸二水素カリウム（和光 特級) および純水（RO膜水, 環境テクノス RTA100W）を用いて作成した。

\section{3. 実験方法}

\section{1）吸着剂の基礎特性}

吸着剂の基礎特性として, 強熱減量, 密度, 粒度, 沈降速度を測定した。強熱減量は含有する有機物量 の目安として利用できる。密度と粒度は粒子の基本 的な物理特性である。沈降速度は, 吸着後の固液分 離の容易さを評価するために測定した。

強熱減量の測定方法は次のと抢りである。るつぼ に $2 \mathrm{~g}$ 程度の吸着剂を量り取り, 電気炉を用いて 600 ${ }^{\circ} \mathrm{C}$ で 2 時間強熱し, 重量減少を測定した。密度測定 はJIS A 1202 に準拠して行い, 脱気には超音波洗浄
器と吸引器を用いた。粒度試験は, 目開き 75,106 , $250,425,500 \mu \mathrm{m}$ のステンレス穊を用い, 振幅 1.8 $\mathrm{mm}$ で 10 分間の振とうによって行った。 沈降速度は, $100 \mathrm{~mL}$ メスシリンダーに吸着剤と純水の混合液を注 入してパラフィルムで密閉し, 手で振とうして十分 に懸濁させた後に静置し, 経過時間ごとの懸濁物上 端の沈降距離を測定することによって求めた。

\section{2）水質分析}

懸濁液の $\mathrm{pH}$ 抢よび電気伝導度 (EC) は, ペンタ イプの測定器（HORIBA B-212 および173）を用いて 測定した。懸濁液はカートリッジ式のろ紙（孔径 $0.45 \mu \mathrm{m}$, ADVANTEC CS045AN） とプラスチックシ リンジを用いてろ過し, 万液を得た。 万液 (吸着剂 を添加していない溶液については, 万過を省略）中 のリン酸濃度を, モリブデン青法 (日本分析化学会 北海道支部, 1996）によって測定した。

\section{3）混合吸着実験}

吸着剂とリン酸溶液との完全混合状態に扔ける吸 着量及び吸着速度の把握のため, 混合吸着実験を 行った。リン酸溶液の濃度は $1 \mathrm{mg}-\mathrm{PO}_{4} / \mathrm{L}$ とし, 一つ の条件ごとに初期量 $1 \mathrm{~L}$ を $1 \mathrm{~L}$ のポリプロピレン製の ビン（以下，ポリビン）に入れて用意した。吸着剤 $0,0.01,0.05,0.1$ および $1 \mathrm{~g}$ を用意し，これら 5 種類の 重量の吸着剂をそれぞれ1 Lのリン酸溶液に混合す る.これらが5つの設定条件であり, 一つの条件ご とに3回の繰り返し実験を行った。水温は, 15〜20 ${ }^{\circ} \mathrm{C}$ 範囲であった.

吸着剂を混合したリン酸溶液をスターラーを用い て擋找混合し, 設定時間経過後の懸濁液を $12 \mathrm{~mL}$ 採 水し，水質分析した。設定時間は, $0,5,10,15,20$, 30,45 分, 1, 2, 3, 6, 12, 24, 36, 48, 60 時間である. 完全

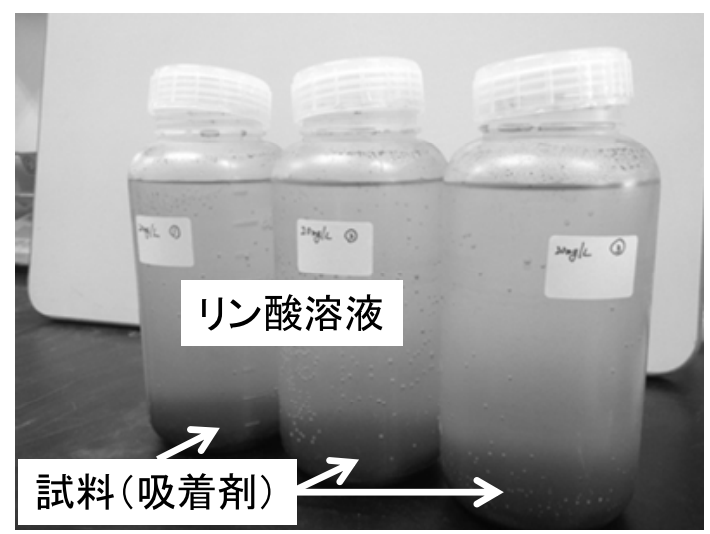

図 -2 浸漬吸着実験

Fig. 2 Absorption experiment using the immersion method. 
混合した懸濁液を採水することから吸着剤とリン酸 溶液の比率が変化しないため, 採水によって吸着剤 とリン酸溶液が減少する影響は無視した。

\section{4）浸漬吸着実験}

吸着剂で構成される平面にリン酸溶液が接し，平 面の法線方向に 1 次元的にリン酸が移動して吸着さ れる場合の吸着速度の把握のため, 浸漬吸着実験を 行った。規定濃度のリン酸溶液を作成し, 初期量 1 Lを $1 \mathrm{~L}$ のポリビンに入れて用意した。そこに規定重 量の吸着剂を静かに投入してポリビンの底に沈殿さ せて吸着剤の平面を構成させた。リン酸濃度と吸着 剂重量の組み合わせは, $20 \mathrm{mg}-\mathrm{PO}_{4} / \mathrm{L}: 8 \mathrm{~g}, 10 \mathrm{mg}-\mathrm{PO}_{4} /$ $\mathrm{L}: 8 \mathrm{~g}, 10 \mathrm{mg}-\mathrm{PO}_{4} / \mathrm{L}: 4 \mathrm{~g}$ 㧍よび $10 \mathrm{mg}-\mathrm{PO}_{4} / \mathrm{L}: 0 \mathrm{~g}$ で ある。それぞれの条件ごとに 3 回の繰り返し実験を 行った。水温は, $15 \sim 20{ }^{\circ} \mathrm{C}$ の範囲であった。浸漬吸 着実験の様子を図一2に示す。

吸着剂を投入したリン酸溶液を静置し，設定時間 経過後の上澄みである懸濁液（懸濁していないが, 便宜上，懸濁液と呼ぶ）を2.5 $6 \mathrm{~mL}$ 採水し，水質 分析した。設定時間は, $0 \sim 224$ 時間中の 33 点（昼間 のみ 2 時間毎に 5 点採水し, 夜間は採水なし) とし た。 上澄みである懸濁液を採水することから吸着剤 とリン酸溶液の比率が変化し, 吸着量への影響があ るが無視した。採水によって損じた最大液量は，初 期量の $1 / 5$ である.

\section{III. 結果}

\section{1. 吸着剤の基礎特性}

吸着剤の強熱減量および密度は，それぞれ $48.8 \%$, $2.1 \mathrm{~g} / \mathrm{cm}^{3}(\mathrm{n}=3$, 平均) であった。吸着剤の粒度試 験の結果を, 図一3に粒径加積曲線によって示す. 75 $\mu \mathrm{m}$ 以下の粒子が $71 \%$ であり, 微細な粒子が大部分 を占めている. $1 \mathrm{~g}$-吸着剤/Lの懸濁液の沈降速度は, $9.3 \mathrm{~mm} / \mathrm{min}(\mathrm{n}=3$, 開始 10 分までの平均) であった。

\section{2. 混合吸着実験}

混合吸着実験によるリン酸濃度の変化を図一4に 示す. 吸着剂 $0 \mathrm{~g}$ 以外, 15 分経過まで液相中リン酸濃 度が減少し，その後拈よそ一定となった。 $\mathrm{pH}$ と EC の最小值〜最大值は，それぞれ $6.4 〜 7.2$ および10〜 $42 \mu \mathrm{S} / \mathrm{cm}$ であった。 ECは吸着剤量が多いほど大き く，また時間経過とともに大きくなった。これは吸 着剂の可溶性成分が混合によって溶出したためと考 えられる。

\section{3. 浸漬吸着実験}

浸漬吸着実験によるリン酸濃度の変化を図一5に 示す。吸着剂 $0 \mathrm{~g}$ 以外, なだらかに液相中リン酸濃

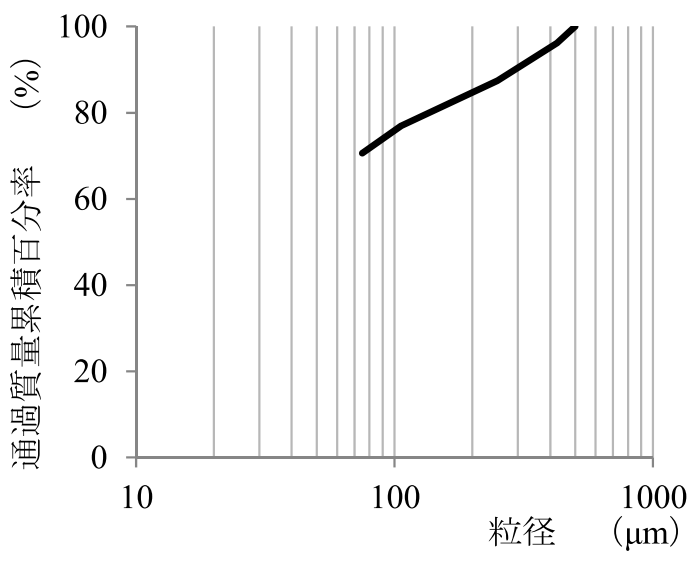

図 - 3 粒径加積曲線

Fig. 3 Particle size distribution.

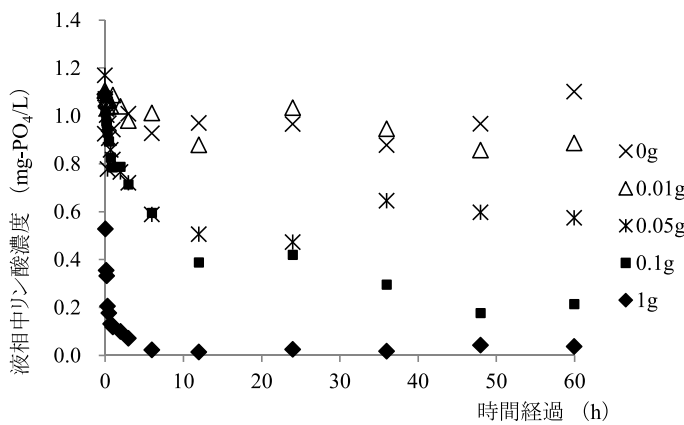

図 -4 混合吸着実験によるリン酸濃度の変化（各条件 に付き, 3 回の平均值)

Fig. 4 Time course of phosphate concentration in the mixing method ( $n=3$, average).

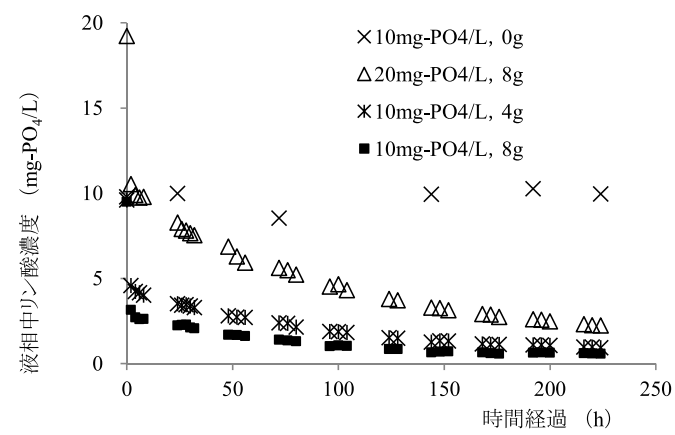

図 - 5 浸漬吸着実験によるリン酸濃度の変化（各条件 に付き, 3 回の平均値)

Fig. 5 Time course of phosphate concentration in the immersion method ( $n=3$, average). 
度が減少した。 $\mathrm{pH}$ と $\mathrm{EC} の$ 最小值〜最大值は，それ ぞれ $6.2 \sim 7.8$ および $16 〜 144 \mu \mathrm{S} / \mathrm{cm}$ であった. $\mathrm{EC} の$ 挙動は混合吸着実験と同様である。

\section{IV. 考察}

\section{1. 吸着等温線}

混合吸着実験の最終濃度を使用して, 吸着等温線 を描いた（図一6）。液相中濃度と吸着量に指数関係 があると見なし，フロイントリッヒ式 $\left(q=a C_{s}{ }^{1 / b}\right)$ に当てはめ, 近似曲線の係数を得た。なお， $q$ : 吸 着量 $\left(\mathrm{kg}-\mathrm{PO}_{4} / \mathrm{kg}\right.$-吸着剂), $C_{S}$ : 吸着剂表面の液相中 濃度 $\left(\mathrm{kg}-\mathrm{PO}_{4} / \mathrm{m}^{3}\right), a$ および $b$ : 係数である. 以上か ら係数として, $a=3.82, b=1 / 0.782=1.28$ を得た。 海野ら（2003）が得た浄水污泥によるリン酸吸着実験 によると, 液相中濃度 $0.0001 \mathrm{~kg}-\mathrm{PO}_{4} / \mathrm{L}$ および 0.001 $\mathrm{kg}-\mathrm{PO}_{4} \mathrm{~L}$ の時, 吸着量はそれぞれ $0.0015 \mathrm{~kg}-\mathrm{PO}_{4} / \mathrm{Kg}$ -

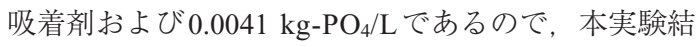
果で得られた吸着能力と同等である。

\section{2. 境膜物質移動容量係数}

吸着の性能を評価する際, 吸着平衡量の他に吸着 速度を把握する必要がある。そこで, 境膜物質移動 容量係数 $\left(K_{L}\right)$ を算出した。 $K_{L}$ を用いた吸着剤への 物質移動の概念を図一7に示す。

全リン酸量は，以下の通り記述できる。

$$
C_{L 0} V=C_{L} V+q W_{d}
$$

フロイントリッヒ式から，

$$
q=a C_{S}^{1 / b}
$$

式1および2からqを消去して

$$
C_{S}=\left[\frac{V}{a W_{d}}\left(C_{L 0}-C_{L}\right)\right]^{b}
$$

一方, 液相中のリン酸の物質収支を考え, 蓄積速 度 $=$ 流入速度 - 流出速度 + 生成速度から,

$$
V \frac{d C_{L}}{d t}=0-K_{L}\left(C_{L}-C_{S}\right) S+0
$$

式3および4から $C_{S}$ を消去して

$$
\frac{d C_{L}}{d t}=-\frac{K_{L} S}{V}\left[C_{L}-\left[\frac{V}{a W_{d}}\left(C_{L 0}-C_{L}\right)\right]^{b}\right]
$$

ここで， $C_{L 0}$ および $C_{L}: t=0$ および $t(h)$ におけ る液相中リン酸濃度 $\left(\mathrm{kg}-\mathrm{PO}_{4} / \mathrm{m}^{3}\right), \quad V$ : 液相容積 $\left(\mathrm{m}^{3}\right), W_{d}$ : 吸着剂重量 $\left(\mathrm{kg}\right.$-吸着剂),$K_{L}$ : 境膜物質 移動容量係数 $(\mathrm{m} / \mathrm{h}), \quad S$ : 吸着剤の表面積 $\left(\mathrm{m}^{2}\right)$ で ある。

なお，吸着剤の比表面積を $s^{\prime}\left(\mathrm{m}^{2} / \mathrm{kg}\right.$-吸着剤）とす れば, $S=s^{\prime} W_{d}$ となるため式 5 は，

$$
\frac{d C_{L}}{d t}=-\frac{\left(K_{L} s^{\prime}\right) W_{d}}{V}\left[C_{L}-\left[\frac{V}{a W_{d}}\left(C_{L 0}-C_{L}\right)\right]^{b}\right]
$$

となる。

浸漬吸着実験において吸着剤はポリビンの底に沈 殿しているため， $S$ はポリビンの内径から計算した. しかし，混合吸着実験では吸着剤は微粒子として分 散しており，吸着材の表面積を求めることが困難で ある。したがって未知のパラメー夕は，混合吸着実 験で式 6 の $K_{L} s^{\prime}$ ，浸漬吸着実験で式 5 の $K_{L}$ である.

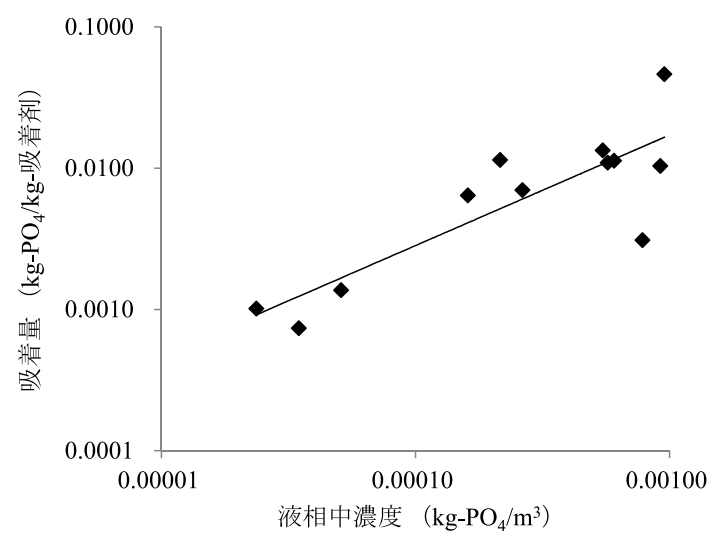

図 - 6 混合吸着実験によるリン酸の吸着等温線

Fig. 6 Absorption isotherm of phosphate in the mixing method.

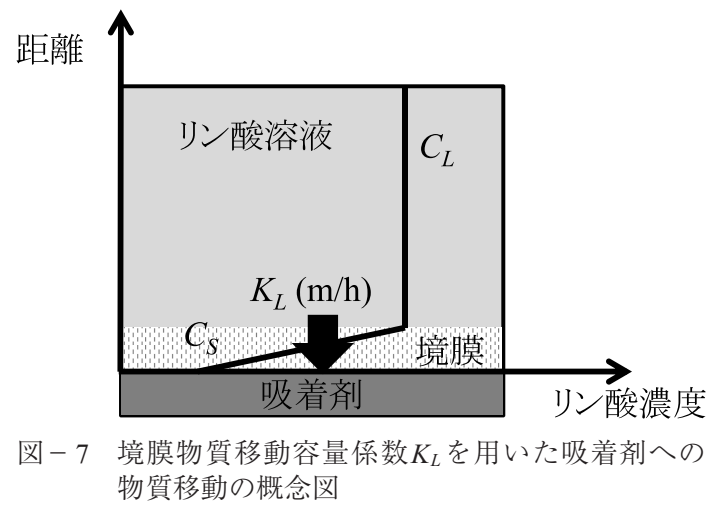

Fig. 7 Schematic diagram of mass transfer to absorbent using $K_{L}$. 


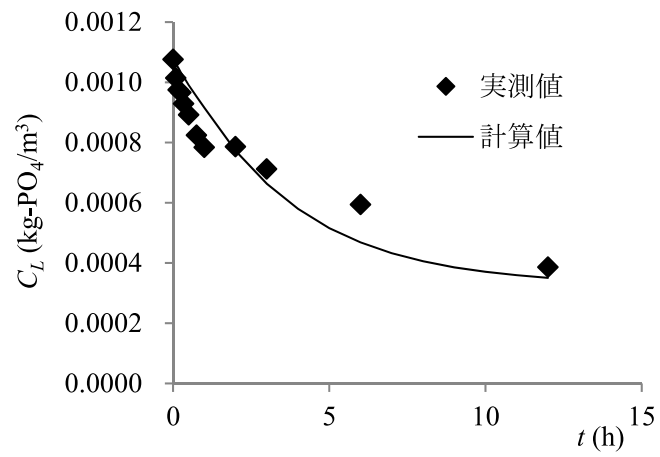

図 -8 混合吸着実験の実測值へのカーブフィッティング (初期リン酸濃度 $1 \mathrm{mg}-\mathrm{PO}_{4} / \mathrm{L}$, 吸着剂量 $0.1 \mathrm{~g}$ )

Fig. 8 Measured values in absorption experiment using the mixing method and fitted curve (initial phosphate concentration, $1 \mathrm{mg}-\mathrm{PO}_{4} / \mathrm{L}$; absorbent, $0.1 \mathrm{~g}$ ).

式 5 および6の解析解を得たのちに，既知のパラ メータを与え, 実測值に対してカーブフィッティン グを行えば, $K_{L} S^{\prime} も し く は K_{L}$ が求められる。 今回は, $t=0$ の初期值（実測值）から $\Delta t$ 後の計算値を微分形 のままオイラー法で求め, この計算值を実測值と合 うようにカーブフィッティングして $K_{L} s^{\prime}$ および $K_{L}$ を 求めた。混合㧍よび浸漬吸着実験の実測值へのカー ブフィッティングの例を図ー8および 9 に，得られ

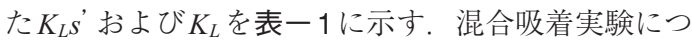
いては， $K_{L} s^{\prime}$ が大きくばらついた。この原因の一つ としては，吸着剤には活性炭の他に土粒子が見られ ることから, 使用する吸着剤の量が少なくなるほど, 構成する土粒子と活性炭の比率の変化によって吸着 量が変化することが考えられる。浸漬吸着実験につ いては, 初期濃度と 2 時間後の濃度が大きく乘離し ている。リン酸溶液中に吸着剂を投入・沈殿させる 際に, リン酸溶液中を吸着剂が通過するため, 半混 合状態となる。したがって, 濃度が乘離する原因は, 沈殿が完了した状態に比べて半混合の状態の吸着の 効率が良いためであると考えられる。そこで, フィッティングには2 時間後以降のデータを用いた。

\section{V．諫早湾干拓調整池リン酸濃度変化の 試算}

\section{1. シミュレーションの理論}

リン酸吸着能力を持つ浄水污泥を用いて, 諫早湾 干拓調整池中のリン酸の除去効果を試算するため に, シミュレーションによって濃度変化を計算した。 吸着の手法として, 2 通りを仮定した. 1 目は, 調

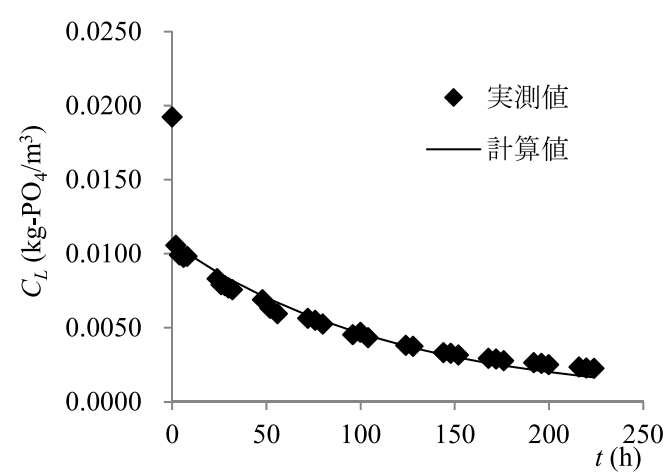

図 - 9 浸漬吸着実験の実測值へのカーブフィッティン グ（初期リン酸濃度 $20 \mathrm{mg}-\mathrm{PO}_{4} / \mathrm{L}$, 吸着剂量 $8 \mathrm{~g}$ )

Fig. 9 Measured values in absorption experiment using the immersion method and fitted curve (initial phosphate concentration, $20 \mathrm{mg}-\mathrm{PO}_{4} / \mathrm{L}$; absorbent, $8 \mathrm{~g}$ ).

$$
\text { 表 }-1 \text { 得られた } K_{L} s^{\prime} \text { およ゙ } K_{L}
$$

Table 1 Measured values of $K_{L} s^{\prime}$ and $K_{L}$

\begin{tabular}{|c|c|c|c|c|c|}
\hline 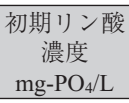 & $\begin{array}{c}\text { 吸着 } \\
\text { 郕量 } \\
\mathrm{g}\end{array}$ & $\begin{array}{c}K L s^{\prime} \\
\mathrm{m}^{3} /(\mathrm{h} \cdot \mathrm{kg})\end{array}$ & $\begin{array}{l}\text { 初期リン酸 } \\
\text { 濃度 } \\
\mathrm{mg} \mathrm{PO}_{4} / \mathrm{L}\end{array}$ & $\begin{array}{c}\text { 吸着 } \\
\text { 郕量 } \\
\mathrm{g}\end{array}$ & $\begin{array}{l}K_{L} \\
\mathrm{~m} / \mathrm{h}\end{array}$ \\
\hline 1 & 1.00 & 4.0 & 20 & 8 & 0.0040 \\
\hline 1 & 0.10 & 1.6 & 10 & 4 & 0.0042 \\
\hline 1 & 0.05 & 10.3 & 10 & 8 & 0.0051 \\
\hline 1 & 0.01 & 3.1 & & & \\
\hline \multicolumn{2}{|c|}{ 平均值 } & 4.7 & \multicolumn{2}{|c|}{ 平均値 } & 0.0044 \\
\hline
\end{tabular}

整池の水をくみだし, 水処理施設において浄水污泥 を用いて完全混合するリン酸除去法（混合法）であ る(図一10). 水処理施設から流出する処理水を調 整池に戻すことによって, 調整池中のリン酸が希釈 される. 2 つ目は, 調整池に浄水污泥を投入する浸漬 法によるリン酸除去法である（図一11）.

ここで， $Q_{i n}, Q_{\text {out }}$ および $Q^{\prime}$ : 流入, 流出および取 水量 $\left(\mathrm{m}^{3} / \mathrm{h}\right), C_{i n}, C_{\text {out }}, C, C_{1}$ 抢よび $C_{2}$ : 流入, 流 出, 調整池中, 取水中㧍よび処理水中濃度 $\left(\mathrm{kg}-\mathrm{PO}_{4} /\right.$ $\left.\mathrm{m}^{3}\right), V$ : および $V^{\prime}:$ 調整池および吸着槽液相容積 $\left(\mathrm{m}^{3}\right), W_{d}$ : 污泥重量 $(\mathrm{kg}), S$ : 調整池面積 $(=$ 污泥

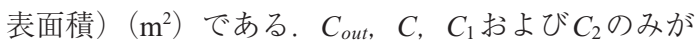
時間 $t(\mathrm{~h})$ の関数であり, 他は一定である. $t=0$ の 状態を，添え字 0 で表現する。

調整池の液相容積が一定とすると,

$$
Q_{\text {in }}=Q_{\text {out }}
$$

調整池の完全混合を想定して,

$$
C_{\text {out }}=C=C_{1}
$$

である。 


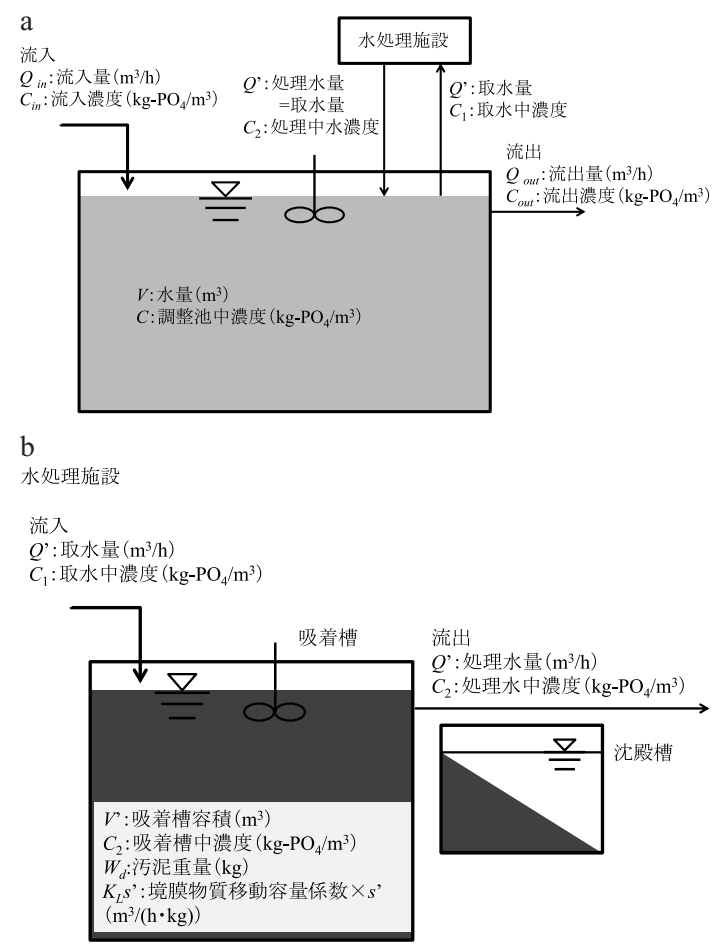

図-10 水処理施設において浄水污泥を用いて完全混 合するリン酸除去（混合法）の概念図（a：調 整池, $\mathrm{b}$ : 水処理施設)

Fig. 10 Schematic diagram of phosphate removal using the mixing method. Water in the reservoir is pumped up into water treatment plant and mixed with sludge (a, reservoir; b, water treatment plant).

まず，混合法について述べる。調整池液相におけ るリン酸収支について, 蓄積速度 $=$ 流入速度 - 流出 速度（生成速度は0）であるから，

$$
V \frac{d C}{d t}=Q_{i n} C_{i n}-Q^{\prime}\left(C_{1}-C_{2}\right)-Q_{o u t} C_{o u t}
$$

式 7,8および9から,

$$
\frac{d C_{\text {out }}}{d t}=\frac{Q_{\text {in }}}{V}\left(C_{\text {in }}-C_{\text {out }}\right)-\frac{Q^{\prime}}{V}\left(C_{\text {out }}-C_{2}\right)
$$

水処理施設におけるリン酸収支について（完全混 合により, 吸着槽中濃度 $=$ 処理水中濃度 $=C_{2}$ ),

$$
V^{\prime} \frac{d C_{2}}{d t}=Q^{\prime} C_{1}-\left(K_{L^{\prime}} s^{\prime}\right) W_{d}\left(C_{2}-C_{S}\right)-Q^{\prime} C_{2}
$$

式 8 および11から，

$$
\frac{d C_{2}}{d t}=\frac{Q^{\prime}}{V^{\prime}}\left(C_{\text {out }}-C_{2}\right)-\frac{\left(K_{L} s^{\prime}\right) W_{d}}{V^{\prime}}\left(C_{2}-C_{S}\right)
$$

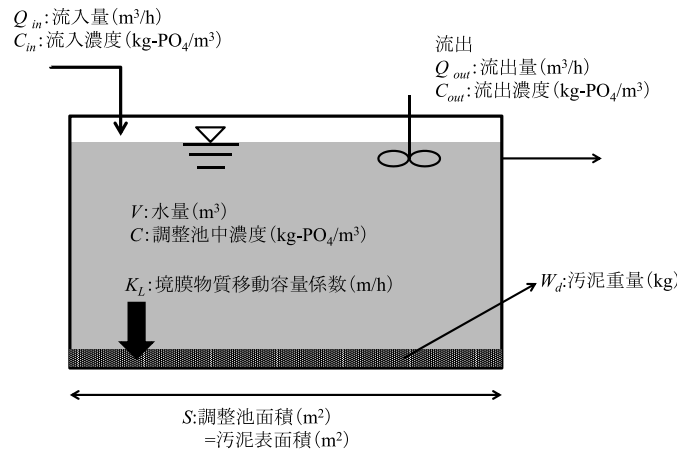

図－11 調整池に浄水污泥を投入する浸漬法によるリ ン酸除去の概念図

Fig. 11 Schematic diagram of phosphate removal using the immersion method. Sludge was added to the reservoir.

污泥が吸着したリン酸量について, $q W_{d}=$ 吸着槽 内リン酸量の減分 $+t$ までの（流入リン酸量－流出リ ン酸量）総量であるから,

$$
q W_{d}=V^{\prime}\left(C_{20}-C_{2}\right)+Q^{\prime} \sum\left(C_{1}-C_{2}\right) \Delta t
$$

式2,8および 13 から,

$$
C_{S}=\left[\frac{1}{a W_{d}}\left\{V^{\prime}\left(C_{20}-C_{2}\right)+Q^{\prime} \sum\left(C_{\text {out }}-C_{2}\right) \Delta t\right\}\right]^{b}
$$

$t=0$ の初期值として $C_{20}=C_{\text {out } 0}, \quad C_{s}=0$ (純水で湿潤 した污泥を $t=0$ に吸着槽に投入したと仮定）を与え， $\Delta t$ 後の式 12 中の $C_{2}$ をオイラー法によって求め, 式 10 中の $C_{\text {out }}$ を同様にオイラー法によって求めた. $C_{\text {out }}$ によって式14から $C_{s}$ が求まる. 以後同様に, 式12中 の $C_{2}$, 式 10 中の $C_{\text {out }}$ を求めることを繰り返した.

次に, 浸漬法について述べる。調整池液相におけ るリン酸収支について, 蓄積速度 $=$ 流入速度 - 流出 速度（生成速度は0）であるから，

$$
V \frac{d C}{d t}=Q_{i n} C_{\text {in }}-K_{L}\left(C_{\text {out }}-C_{S}\right) S-Q_{\text {out }} C_{\text {out }}
$$

污泥が吸着したリン酸量について, $q W_{d}=$ 調整池 内リン酸量の減分 $+t$ までの（流入リン酸量－流出リ ン酸量）総量であるから,

$$
q W_{d}=V\left(C_{0}-C_{\text {out }}\right)+Q_{\text {in }} \sum\left(C_{\text {in }}-C_{\text {out }}\right) \Delta t
$$

式2および16から，

$$
C_{S}=\left[\frac{1}{a W_{d}}\left\{V\left(C_{0}-C_{\text {out }}\right)+Q_{\text {in }} \sum\left(C_{\text {in }}-C_{\text {out }}\right) \Delta t\right\}\right]^{b}
$$

式 7, 8, 15および 17 から, 


$$
\begin{aligned}
& \frac{d C_{\text {out }}}{d t}=\frac{Q_{\text {in }}}{V}\left(C_{\text {in }}-C_{\text {out }}\right) \\
& -\frac{K_{L} S}{V}\left[C_{\text {out }}-\left[\frac{1}{a W_{d}}\left\{V\left(C_{\text {out } 0}-C_{\text {out }}\right)+Q_{\text {in }} \sum\left(C_{\text {in }}-C_{\text {out }}\right) \Delta t\right\}\right]\right.
\end{aligned}
$$

$t=0$ の初期值として $C_{\text {out } 0}$ を与え, $\Delta t$ 後の式 18 中の Cout をオイラー法によって求めた.

\section{2. 設定条件}

シミュレーションを行うに当たって設定した条件 は，表一2および3の通りである。 なお， $C_{\text {out } 0}=C_{0}$ である。また前述のように，全リンがすべてリン酸 として存在すると仮定して, リン酸濃度に換算して いる.

\section{3. シミュレーション結果}

\section{1) 混合法}

混合法のシミュレーション結果を図ー12に示す (条件は，表一4を参照)。文献值から設定した初期 のリン酸濃度は, 調整池よりも流入河川中の方が低 い.したがって，計算上は流入河川による希釈のた め調整池中の濃度が減少する。この様子は図一12の 污泥無しの曲線で示している。この曲線以下となる のは，污泥による吸着効果である，吸着によって処 理水中濃度 $C_{2}$ が低下し, 調整池を希釈するため, 調 整池中濃度 $C\left(=C_{\text {out }}\right)$ が低下する。吸着槽容積 $V$ のみを増加させると, 短期間でリン酸吸着が飽和し,

\section{表 -2 調整池㧍よび流入河川の規模}

Table 2 Dimensions of adjustment reservoir in Isahaya reclaimed land and inflowing river.

\begin{tabular}{c|c|c|c|c}
\hline & 面積 $^{\mathrm{a}}$ & $S$ & $\mathrm{~m}^{2}$ & $2.6 \times 10^{7}$ \\
調整池 & 平均水深 $^{\mathrm{a}}$ & - & $\mathrm{m}$ & $1.4 \times 10^{0}$ \\
& 容積 & $V$ & $\mathrm{~m}^{3}$ & $3.6 \times 10^{7}$ \\
流入河川 & 流入量 $^{\mathrm{b}}$ & $Q_{i n}$ & $\mathrm{~m}^{3} / \mathrm{h}$ & $9.3 \times 10^{3}$ \\
\hline
\end{tabular}

表 -3 調整池扔よび流入河川のリン濃度

Table 3 Phosphate concentrations in water from the reservoirand inflowing river.

\begin{tabular}{c|c|c|c}
\hline \multicolumn{2}{l|}{} & $\mathrm{kg}-\mathrm{P} / \mathrm{m}^{3}$ & $\mathrm{~kg}-\mathrm{PO}_{4} / \mathrm{m}^{3}$ \\
\hline 調整池 $^{\mathrm{a}}$ & $C_{0}$ & $2.1 \times 10^{-4}$ & $6.4 \times 10^{-4}$ \\
環境基準 $^{\mathrm{a}}$ & $C_{i n}$ & $1.3 \times 10^{-4}$ & $4.1 \times 10^{-4}$ \\
流入河川 $^{\mathrm{b}}$ & - & $1.0 \times 10^{-4}$ & $3.1 \times 10^{-4}$ \\
\hline
\end{tabular}

注：調整池は1997〜2006年の平均, 流入河川は2006 2011年の平均

a ：長崎県（2008）

b：横瀬ら (2007)
むしろ $C_{2}$ は増加する. 次に, 取水量 $Q^{\prime}$ のみを増加 させると, 初期の $C_{2}$ は鋭敏に減少するが，短期間で リン酸吸着が飽和し， $C_{2}$ は $C_{\text {out }}$ と同様の濃度まで速 やかに戻る（上昇する）。なお， $Q$ を減少させると， Cが低下するために必要な時間が長くなる，最後に， 污泥重量 $\mathrm{Wd}$ のみを増加させると，単純にリン酸吸 着総量が上がるので， $C_{2}$ が減少する，なお， $W_{d}$ を 極端に大きくすると，式12によって（吸着速度が大 きいために） $C_{2}$ が負になり計算結果が発散しやすい.

1 年後に環境基準值以下となる条件を探索した。 吸着量がすぐに飽和に達するため, 1 月に 1 度, 污泥 を新しいものに取り換えることとした，探索された 結果はお抄むね表一 4 の通りである。表一 4 中の污

表-4 1 年で環境基準以下となる設定条件（混合法）

Table 4 Conditions to achieve environmental standards in one year using the mixing method.

\begin{tabular}{c|c|c|c|c|c}
\hline & & & 条件 1 & 条件2 & 条件3 \\
\hline 吸着槽容積 & $V^{\prime}$ & $\mathrm{m}^{3}$ & $5.0 \times 10^{7}$ & $5.0 \times 10^{6}$ & $5.0 \times 10^{5}$ \\
取水量 & $Q^{\prime}$ & $\mathrm{m}^{3}$ & $5.0 \times 10^{6}$ & $5.0 \times 10^{5}$ & $5.0 \times 10^{4}$ \\
污泥重量 & $W_{d}$ & $\mathrm{t}$ & 300 & 150 & 150 \\
\hline
\end{tabular}

表 - 5 環境基準以下を維持する設定条件（混合法）

Table 5 Conditions to maintain environmental standards using the mixing method.

\begin{tabular}{c|c|c|c}
\hline $\begin{array}{c}\text { 交換頻度 } \\
\text { 回/年 }\end{array}$ & $\begin{array}{c}\text { 条件 } 1 \\
\mathrm{t} / \text { 回 }\end{array}$ & $\begin{array}{c}\text { 条件 } 2 \\
\mathrm{t} / \text { 回 }\end{array}$ & $\begin{array}{c}\text { 条件 } 3 \\
\mathrm{t} / \text { 回 }\end{array}$ \\
\hline 2 & 1,000 & 1,000 & 発散 \\
4 & 400 & 400 & 400 \\
6 & 300 & 300 & 300 \\
12 & 115 & 120 & 120 \\
\hline
\end{tabular}

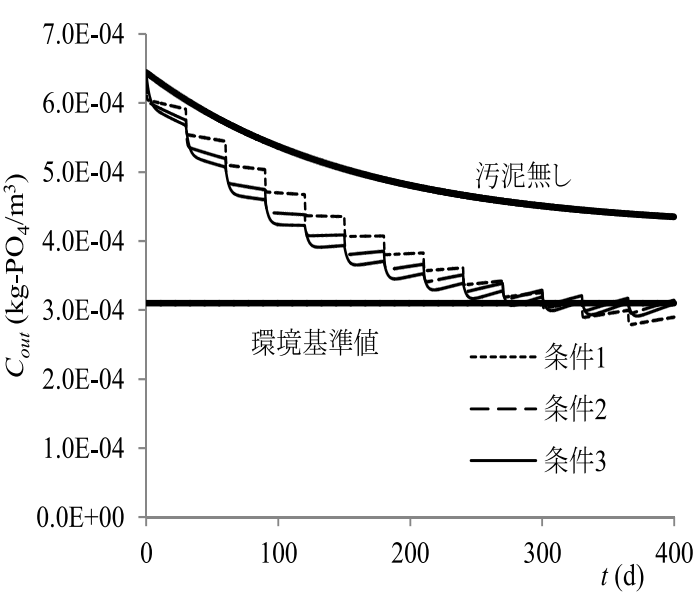

図-12 混合法シミュレーション結果

Fig. 12 Simulation of phosphate concentration in the mixing method. 


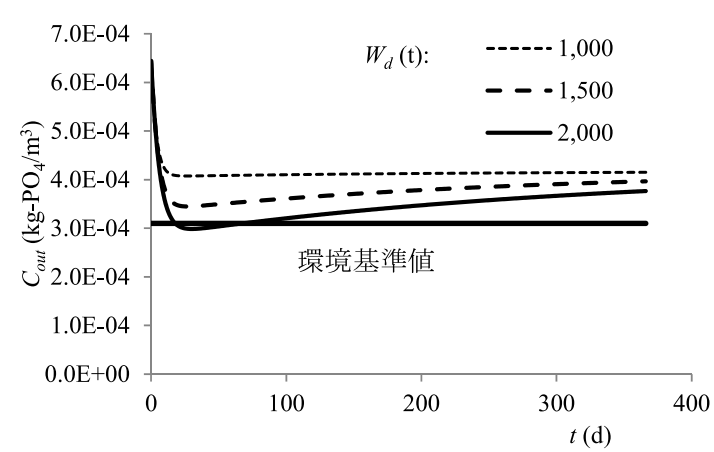

図 - 13 浸漬法シミュレーション結果

Fig. 13 Simulation of phosphate concentration in the immersion method.

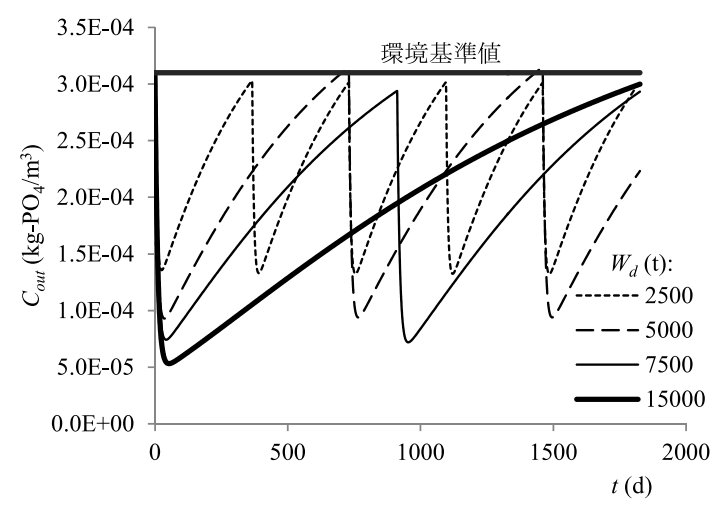

図ー 14 環境基準值以下を維持したときの浸漬法シ ミュレーション結果

Fig. 14 Simulation of phosphate concentration to maintain environmental standards using the immersion method.

泥量は, 1 月当たりのものである.

次に, 環境基準值以下の維持に必要な污泥量を探 索した結果を表一 5 に示す。吸着槽容積や取水量の 影響は少なく, 交換頻度によって污泥量が決められ, お扮むね 1 年間で $1,400 \sim 2,000 \mathrm{t}$ 必要であることが分 かった。

\section{2）浸漬法}

浸漬法のシミュレーション結果を図ー13に示す。 条件設定できるのは $W_{d}$ のみである。まず，環境基 準值以下となるための $W_{d}$ を探索したところ，図一 13 に示す通り2,000 t程度であった。しかし吸着量が 飽和するため, 環境基準值以下の維持には新しい污 泥の投入が必要になる。ここで，環境基準值を達成 した後，引き続き環境基準值以下の維持に必要な污 泥量を探索した結果を表一6に, その時のCの変化
表 -6 環境基準以下を維持する設定条件（浸漬法）

Table 6 Conditions to maintain environmental standards using the immersion method.

\begin{tabular}{c|c}
\hline $\begin{array}{c}\text { 交換頻度 } \\
\text { 回/10年 }\end{array}$ & $\begin{array}{c}\text { 污泥重量 } W_{d} \\
\mathrm{t} / \text { 回 }\end{array}$ \\
\hline 2 & 15,000 \\
4 & 7,500 \\
6 & 5,000 \\
12 & 2,500 \\
\hline
\end{tabular}

を図ー 14 に示す. 10 年間で 30,000 t必要であり，そ れを 2 回以上の頻度で分割して投入すればよいこと が分かった，すなわち， 1 年間で 3,000 t必要である。

\section{3）シミュレーション結果の考察}

混合法抢よび浸漬法とも, 必要な污泥量は平山浄 水場から発生する污泥量と同じオーダーであった. 混合法では, 構造上, 使用済み污泥を取り出すこと ができる（リン酸を調整池から取り出せる）ものの, $5.0 \times 10^{5} \mathrm{~m}^{3}$ という巨大な吸着槽が必要である。浸漬 法では, 毎年 3,000 tの污泥を調整池中に投入・堆積 する上に, 結局調整池の内部からリン酸は取り出し ていないという欠点がある.

\section{VI. まとめ}

調整池の水をくみだし, 水処理施設において浄水 污泥を用いて完全混合するリン酸除去法では，おお むね 1 年間で $1,400 \sim 2,000 \mathrm{t}$ の污泥が必要であること が分かった。 調整池に浄水污泥を投入する浸漬法に よるリン酸除去法では, 1 年間で $3,000 \mathrm{t}$ の污泥が必要 であることが分かった。 なお, 2011 年度の平山浄水 場の浄水污泥発生量は, $2,039 \mathrm{t}$ である。混合法では, 巨大な吸着槽（例えば $10^{5} \mathrm{~m}^{3}$ のオーダー）が必要で あり，浸漬法では污泥を調整池に投入したままとな り，また調整池からリンを取り除いていないという 欠点がある. 浄水污泥はリン酸除去に利用可能であ るが，必要量や施設規模が膨大であるため，さらな る検討が必要である。

\section{付記}

本研究を進めるにあたり, 平成 24 年度卒業生であ る権藤大志君には, 実験の実施に多大な協力をいた だきました。また，浄水污泥をご提供いただきまし た諫早市に感謝申し上げます。な扮，研究テーマ設 定, 方針の決定, 試料採取および予備実験は, 武政 
剛弘が担当した。シミュレーション原案は中川啓が 担当した。実験実施，解析，シミュレーションは朝 倉宏が担当した。

\section{引用文献}

Boki K, Tanaka S. 1987. Phosphate removal by adsorption to activated carbon. Japanese Journal of Hygiene 42: 710-720.

諫早湾干拓調整池等水質委員会 2007. “諫早湾干拓調整池等水質 委員会検討結果の取りまとめ”, 九州農政局, http://www.maff. go.jp/kyusyu/nn/isahaya/news/20071226kentou.pdf. (参照: 2013/05/10)

Kim JG, Kim JH, Moon HS, Chon CM, Ahn, JS. 2003. Removal capacity of water plant alum sludge for phosphorus in aqueous solutions. Chemical Speciation and Bioavailability 14: 67-73. DOI: http://dx.doi.org/10.3184/095422902782775344 国土交通省 (土地・水資源局水資源部）2007. “日本の水資源”，国 土交通省, http://www.mlit.go.jp/tochimizushigen/mizsei/ hakusyo/H19/index.html. (参照:2013/05/10).

厚生労働省（健康局水道課）2010. “浄水污泥（浄水発生土）の循 環利用について”, 平成22年度 第58回循環型社会計画部会議 資料, http://www.env.go.jp/council/former2013/04recycle/ y040-58/mat04.pdf. (参照:2013/05/10).

九州農政局 2003. “諫早湾干拓事業開門総合調査報告書(案)”, 第6回中・長期開門調査検討会議配付資料, http://www.maff.go.jp/ j/study/other/kaimon/06/pdf/data2_1.pdf. (参照:2013/05/10).

九州農政局 2013. “環境モニタリング調査結果”, 諫早湾干拓事業, http://www.maff.go.jp/kyusyu/nn/syoukai/kankyou_monitoring/ monita.htm. (参照:2013/05/10).

李 洪源・権藤道直・松永信博・千葉 賢・清水康弘 2011. 諫早湾 潮受け堤防排水門背後の底泥中における物質循環の解析. 土木 学会論文集B2 (海岸工学) 67:| 891-I 895.
長崎県 2008. “第2期諫早湾干拓調整池水辺環境の保全と創造の ための行動計画”, 諫早湾干拓調整池水質保全計画, https:// www.pref.nagasaki.jp/shared/uploads/2013/05/1367993291. pdf. (参照:2013/05/10).

長崎県 2013. “産業廃棄物処理計画書”, (特別管理) 産業廃棄物 多量排出事業者 H24年度分提出状況, https://www. pref. nagasaki.jp/shared/uploads/2013/08/1376288712.pdf. (参照: 2013/05/10).

日本分析化学会北海道支部編 1996. 水の分析-第4版-. 化学同 人;269-271.

仁木将人・西田 渉·野口正人・橋本篤史 1999. 諫早調整池におけ る水質変化の予測とその評価に関する研究. 水工学論文集43: 1007-1012.

佐々木克之・程木義邦・村上哲生 2003. 諌早湾調整池からの COD·全窒素・全リンの排出量および失われた浄化量の推定. 海の研究12:573-591.

海野修司・岡本正美・永㴊正夫 2003. 浄水污泥を用いたリン除去 技術. 土木学会論文集741/VII-28:111-121.

浦野絋平 1988. 吸着法によるリン除去技術. 水質污濁研究11: 623-627.

Yang Y, Zhao YQ, Babatunde AO, Wang L, Ren YX, Han Y. 2006. Characteristics and mechanisms of phosphate adsorption on dewaterd alum sludge. Separation and Purification Technology 51:193-200. DOI: http://dx.doi.org/10.1016/j. seppur.2006.01.013

横瀬 健·川井仁·浦 伸孝·荒木昌彦·粕谷智之·本多 隆 2007. 諫早湾干拓調整池水質等調査結果 (2007年度). 長崎県環境保 健研究センター所報53:109-113.

（受付：2013年 6 月 3 日, 受理：2013年 12 月 3 日）

この論文への討議・コメントを, 2014年11月末日 まで受け付けます。 


\title{
Evaluation of Phosphate Removal Using Purification Plant Sludge and Simulation of Concentration Change in an Adjustment Reservoir in Isahaya Reclaimed Land
}

\author{
Hiroshi ASAKURA ${ }^{1)}$ Kei NAKAGAWA ${ }^{1)}$ Takehiro TAKEMASA ${ }^{2)}$ \\ 1) Nagasaki University \\ (1-14 Bunkyo-machi, Nagasaki 852-8521, Japan) \\ 2) Chiiki-souzou Nagasaki \\ (1-43 Dejima-machi, Nagasaki 850-0862, Japan)
}

Total phosphorus in water from an adjustment reservoir in Isahaya reclaimed land has regularly exceeded environmental standards. However, sludge from purification plants is known to have the capacity to absorb phosphate. In this study, to promote recycling of sludge and to develop a method for total phosphorus reduction, evaluation of phosphate removal by sludge from a purification plant was performed, in addition to simulation of concentration changes in an adjustment reservoir to which sludge was added. Absorption experiments were conducted using a mixture of phosphate solution and sludge. The coefficient of absorption isotherm and the mass transfer capacity coefficient were measured in relation to the absorption rate. During mixing, water in the reservoir is pumped into the water treatment plant. Phosphate is removed from it by complete mixing with sludge of about $1,400-2,000 \mathrm{t} / \mathrm{y}$ of sludge. When using the immersion method, sludge is added to the reservoir. Approximately 3,000 t/y of sludge is required. However, both methods have shortcomings: a huge absorption tank (e.g. the order of $10^{5}$ $\mathrm{m}^{3}$ ) must be used for mixing; in the immersion method, sludge remains in the adjustment reservoir and phosphate is not removed from the reservoir. Because the required amount of sludge and scale of treatment plant are large, further investigation is necessary.

Key words : absorption, phosphate, sludge from purification plant, mass transfer capacity coefficient 